\title{
Crossing Consciousness: A literature discussion exploring friends from the other side.
}

Julia López-Robertson

\begin{abstract}
This article will focus on the use of small group literature discussions as a curricular engagement that challenges children to think critically and to share the opinions they are forming about the books they read. This teacher research study took place in a bilingual second grade classroom and describes the discourse of four young bilingual children during a discussion about the book Friends From the Other Side/Amigos del otro lado (Anzaldúa, 1993). The question guiding the research is; how do young linguistically and socio economically diverse children make meaning from small group literature discussions about issues that relate to their lives?
\end{abstract}

Key words: literature discussions, discourse, diversity.

\section{Resumen}

Este artículo se enfoca en el uso de pequeños grupos de discusión literaria como un compromiso curricular que reta a los niños y niñas a pensar críticamente y a compartir las opiniones que ellos se están formando acerca de los libros que leen. Esta investigación se llevó a cabo en un colegio bilingue con el grado segundo y describe el discurso de cuatro niños bilingües durante una discusión sobre el libro Friends From the Other Side/Amigos del otro lado (Anzaldúa, 1993). La pregunta que guía la investigación es ¿Cómo los niños linguistica y socioeconómicamente diferentes construyen significado desde discusiones en pequeños grupos literarios acerca de temas que se relacionan con sus vidas?

Palabras claves: Discusiones literarias, discurso, diversidad.

Many linguistically and culturally diverse students from lower socio-eco- 
nomic backgrounds are performing poorly academically in schools (Cummins, 1989). While there are many possible reasons, one issue is that schools as a whole do not value the types of knowledge these students bring to the classroom. Instead of seeing that these children's lives are full of literary experiences and that they have begun their learning before they even enter school (Moraes, 1996; Valdez, 1996; Purcell-Gates, 1995; Barnes, 1993; Heath, 1983; Ferreiro \& Teberosky, 1982; Taylor \& Dorsey-Gaines, 1986; Vygotsky, 1978) schools view these students as deficient and treat their experiences as though they are detrimental to their learning.

Because these children from linguistically and socio-economically diverse homes come to school lacking what some consider fundamental knowledge and verbal skills, well-meaning educators present these children with unchallenging curriculum that stresses basic skills. These children are not asked to think critically (Diaz, Moll, \& Mehan, 1990; Martínez-Roldán \& López-Robertson, 2000) and may therefore never reach their full potential. Children's different ways of constructing literacy should not be seen as an obstacle to their education.

This article will focus on the use of small group literature discussions in a primary bilingual classroom as a curricular engagement that challenges children to think critically and to share the opinions they are forming about the books they read. The study took place in a bilingual second grade classroom on the south side of Tucson, Arizona and focused on a discussion about the book Friends from the Other Side/Amigos del otro lado (Anzaldúa, 1993). This teacher research study was guided by the question, How do young linguistically and socioeconmically diverse children make meaning from small group literature discussions about issues that relate to their lives?

\section{Theoretical Frame for Response}

Small group literature discussions are literature circles where a small group of students who have read, or who have had the book read to them, sit and discuss the meaning they are creating from their understandings and personal connections (Short, 1995, 1997). During small group literature discussions, the children talk with other children and the teacher about their meaning making about a particular book. These discussions are in line with Vygotsky's (1978) theory concerning a Zone of Proximal Development, "the distance between 
the actual developmental level as determined by independent problem solving and the level of potential development as determined through problem solving under adult guidance or in collaboration with more capable peers" (p. 86) and take into account his belief that learning is a social process. These literature discussions also support Vygotsky's (1986) stance that school learning is largely informed by the interactions occurring in the home and that the most effective school learning takes place when a meaningful connection is made between the home and the school.

While participating in these discussions children carefully listen to each other and think about what is being shared. They learn to take a stance (Rosenblatt, 1978) and at the same time they learn to respect the different interpretations others may have about the same text. Children draw on personal experiences to make connections with the text and with what someone else has shared during a discussion. The children bring their experiences to the text and begin to create personal meaning in combination with the text. They share these beginning understandings with the children in the discussion group while they are involved in what Rosenblatt (1995) called a "two-way reciprocal relation" (p. 27) with the text; as the children search for meaning they are constructing and interpreting the text they have all read, the life experiences they are sharing and listening to and the new meanings they are creating from the discussion.

\section{Research on Literature Discussions}

While researching literature discussions, most of the studies I found dealt primarily with students in the intermediate grades, and were mostly set in mainstream classrooms, not bilingual ones such as mine. A few studies have been done with second-language learners in mainstream classrooms. Although these studies revealed that diverse learners can engage in meaningful talk about texts and that they benefit from the support given from their peers, their area of interest was in how the discussions help the students acquire English (Brock, 1997; Raphael, Brock \& Wallace, 1997; Cox \& Boyd-Batstone, 1997).

I found a few studies about small-group literature discussions in primary bilingual classrooms. The focus of these studies ranged from: the identification of conditions that promoted or encouraged communication between the children and teacher (Battle, 1993), the discovery that student-generated questions motivated children to learn and participate more during their storybook 
discussions than teacher-generated questions (Commeyras, 1994), and finally Sipe's (1998) study which determined that children bring their own unique perspectives to understanding and interpreting a text. All of the aforementioned studies took place in mono-lingual classrooms where the language of instruction was English.

Martínez-Roldán E López-Robertson (2000), a study undertaken in a bilingual first grade classroom, explored the kind of talk the children engaged in during small group literature discussions in Spanish and whether these young children are able to think and talk thoughtfully about children's books. The authors found that, "young bilingual children, no matter their linguistic background, are able to have rich discussions if they have regular opportunities to engage with books from a transactional perspective." (p. 279).

The study cited above is the only one found where children are participating in literature discussions in Spanish. In fact Martínez-Roldán (2003) found, "no research on literature discussions in bilingual classrooms can be found in recent reviews about research on response to literature" (p. 493).

\section{Research Context}

This teacher research study grew from a desire to understand my students, and the connections they were making during our literature discussions. I wanted to see things from their point of view and I also wanted them to be active participants in my research; to become my 'informants' (Hubbard E Power, 1993).

This study took place in my bilingual second grade classroom located on the south side of Tucson, Arizona. I participate in the looping strand which means that I have the children for two years, in this case first and second grade. Wyman School (a pseudonym) is a Title I school located in an urban area surrounded by businesses, homes, several places of worship representing various religions, schools, and apartment buildings. Of the almost 680 children who attend Wyman School most are within walking distance, while about $10 \%$ are bussed to the school to participate in the Bilingual Gifted Program (the only one in the district). Almost $97 \%$ of the children receive free or reduced lunch. This is the largest bilingual school in the district.

\section{Curriculum}


The children are invited to participate in a variety of literacy related engagements that take place during the language arts block such as; Guided Reading Groups, Writer's Workshop, Reader's Workshop and literature discussions. Small group literature discussions take place twice a week usually on Wednesday and Friday and are always related to the general unit of study. Making the discussions a part of the general unit of study aids the children in making the intertextual connections so necessary in seeing the curriculum as a whole rather than as segmented bits and pieces (Short, 1992).

Prior to beginning the literature discussions I invited the families to an informational meeting at school where I described the literature discussions, explained their significance and talked about where they fit in the Language Arts and Social Studies curriculum. Also during that meeting I provided samples of the books to be used and explained the procedures and expectations for the home component when the children take the books home. Families were encouraged to ask questions during the meeting and to discuss all of the information at home and contact me later if there were any questions. After about a week all questions were responded to and we were ready to begin the discussions.

\section{Procedures for Literature Discussions}

I read aloud the book we will discuss the week before the discussion group in English and in Spanish, that way I am assured that every child has heard the book at least once before we discuss it. On Monday, four or five children volunteer to be part of Wednesday's discussion group. They take home the books that evening and keep them until Wednesday. The books are sent home in a plastic zip top bag along with some post its and a note explaining the home assignment. (Recall that this has all been explained to the families at the the first night, the children read and discuss the book with an adult. The second night, the night before the discussion, the children look for at least three parts of the book they wish to share with their group; they put a post-it on each of these three sections. These are parts they have questions about, have made a connection with, are unclear about something, find a reminder to something that happened in their lives or simply be a part they wish to share.

The following day during the small group literature discussion, the children share these three parts they have identified at home as starting off points for their discussion. Sometimes the children write notes on the post-it so they do not forget what they wanted to say to their group. The children in the discus- 
sion group and I sit around the audio tape recorder at the main rug area in the classroom while the other children are sitting at their tables working on a written and illustrated response to the book During the discussion, I take field notes and participate in the discussion as a group member, discussions generally last anywhere between 20 and 40 minutes.

\section{The Participants}

Literature discussions have been a part of the classroom curriculum since the children were in the first grade with me and as a result, the children are very comfortable discussing their ideas and opinions and sharing their beginning understandings with each other. This study took place during the spring semester of the second grade and although the study took place in my classroom and all students participated, this study focused on four children and their responses during one literature discussion about the book Friends From the Other Side/Amigos del otro lado (Anzaldúa, 1993). In this story a young boy and his mother have just arrived in the United States from Mexico. They are very poor and live in a broken down shack in a town near the border. The story traces a day in the life of Joaquin, the son, as he encounters some neighborhood boys who tease him and call him names, mojado, until a young girl, Prietita saves him.

These four children were selected because of the intensity of the personal connections they made with the events taking place in the story. While most of the children in the classroom made personal connections with the characters and events in the story, Jasmine, Javier, Rosita and Miguel's connections were considerably more descriptive and passionate. All four of the children had been with me in the first grade the previous year, all four of the children are first-generation Mexican American and all four children are English Language Learners.

Jasmine was eight-years-old at the time of the study. She was extremely quiet and reserved; she only spoke when asked a question and even then her responses were very limited although rather powerful. Javier was also eightyears old; he too was very shy and rather soft spoken. Javier gained a lot more self-confidence in the second grade and eagerly shared his ideas and opinions. Rosita was seven-years old and was quietly outspoken; she shared her opinions freely and was at the same time a little guarded. Miguel was 
eight-years old and always shared his opinions freely and questioned other's interpretations in order to better understand them.

\section{Data Collection and Analysis}

In addition to field notes taken in a teacher's journal during the discussions, all discussions were completely audio taped and selectively transcribed. Prior to completely transcribing an audiotape, I listened to the entire discussion in order to get an overall feel for the discussion and interactions. Discussions that were completely transcribed were those where I felt the children participated in more actively and where their responses demonstrated they were examining their life experiences and connecting them to the book we read. Written artifacts such as the children's sketch to stretch (Short, Harste, E Burke, 1990), webs containing initial responses shared during the whole class discussion and literature log entries were collected. Combining these data sources I used the constant comparative method (Glasser $\mathcal{E}$ Strauss, 1967) to create categories from the data to describe the kind of connections the children were making in the literature discussion.

The categories I developed from the data were Sharing life stories, Questioning and Interpreting.

\section{Sharing Life Stories}

The category of Sharing Life Stories is divided into two subcategories; Life Knowledge and Life Experience. Sharing Life Stories: Life Knowledge looks at the children's responses when they are putting themselves into the story or empathizing with a character; the children are sharing stories of things they have witnessed but have not happened to them or directly affected them or their families. (The children spoke in Spanish during the discussion, the English translation is provided below the children's original Spanish words.)

Yo el otro día vi un mojadito y le dije ¡Córrele, porque allí viene la migra!

[The other day I saw a wetback and I told him "Run the border patrol is coming!"] 
Miguel's personal connection with the scene in the story where the Border Patrol has just arrived in the pueblito searching for 'illegals' demonstrates his search for understanding through making a personal connection. Miguel shared this brief episode from his life as a way to make sense of what was happening in the story. Because he visits Nogales, Mexico on a weekly basis with his grandfather, he can tell countless stories of witnessing injustices by the Border Patrol and townspeople as well.

Un señor en Nogales, le gritó a otro señor que se esta brincando un cerco allí, "Mojadito" le gritó, "Bájate de allí" y el señor, el mojadito, iba más recio y se brincó el cerco y se vino [a los Estados Unidos] corriendo.

[A man in Nogales, yelled at another man that was jumping the fence, "Wetback" he yelled, "Get off of there" and the man, the wetback, went even faster and jumped the fence and came over [to the United States] running.]

Miguel's way of making sense of these things happening in the text is to relate them to events he has witnessed. Although the events he shared have not happened directly to him, their impact has been made and they have become a part of him. Purcell-Gates (1995) describes the sociocultural theory of learning: "all learners are seen as members of a defined culture, and their identity with this culture determines what they will encode about the world and the ways in which they will interpret information."(p.4). Miguel's way of interpreting information and making sense of it, in this literature discussion, is to relate it to events that he has seen take place.

\section{Sharing Life Stories: Life Experience}

These responses focus on connections to experiences the children have lived through; personal experiences that have directly affected them and their families. I believe all of the children feel safe to share these personal experiences in the classroom. We have worked hard to create a safe caring classroom. Our literature discussions have allowed the children to express their thoughts, fears and ideas without any shame and without the fear that we will judge them. The discussions have enabled us to learn about each other and build trust; "This trust has enabled us to establish and sustain a learning community" (Pierce E Gilles, 1993, p. ix).

A mi me hizo recordar cuando, um, los señores enseguida de mi casa le gritaron a mi mamá y a mi tío y a mi tía...les tumbaron la puerta [la 
migra], y luego entraron y se los llevaron a todos. Yo me tuve que quedar con mi nana.

[It reminded me of when, um, the men next to my house yelled at my mom, my uncle, and my aunt...they [Border Patrol] knocked the door down, and then they went in and took them all away. I had to stay with my grandmother.]

Rosita shared this story very openly with us while pointing to the part in the book where the Border Patrol has arrived in the barrio to do a sweep. Later in an interview, Rosita added that she did not understand why the neighbors did that to her family "Nosotros nunca le hemos hecho nada mal a ellos." [We've never done anything wrong to them.] She also shared that she and he brother had to live with their grandmother until her mother was able to come back to Tucson, which I later learned was about four months. I asked her if she remembered how old she was, "Yo estaba en Kinder." [I was in Kindergarten.]

On the day this happened, Rosita told me that she came home from school and there was no one home. She and her brother had been told that in the event no one was home upon their return from school, to go straight to their grandmother's house. When they arrived at their grandmother's house, "Mi hermano sabía que algo no estaba bien." [My brother knew something wasn't right.] Rosita added, "Yo me diverti con mi nana, pero me hacía falta mi mama." [I had fun with my nana, but I needed my mom.]

For Rosita the scene in the text when the Border Patrol comes to the village to take people away was all too real. Although this difficult experience happened when she was only five-years-old, I can imagine that it is something she will never forget. Vygotsky (1986) argues for the necessity of creating meaningful connections between the home and school in order to maximize children's cognitive development. Through literature discussions the children are able to do this as they search their lives in order to make connections between their lives and the book we are discussing.

\section{Questioning}

Questioning is an integral part of any classroom however, with the focus mainly on the teacher's questions, educators have failed to give needed attention to 
the children's questions. Traditionally questions have been used by teachers as a method of evaluating what the children have been taught. The model followed mostly in classrooms has been the "Initiation/ Response/ Evaluation (IRE)-that best fits the transmission of facts and routinized procedures" (Cazden, 2001, p. 5).

Children come to school full of questions about things they want to know; these are the "sincere questions, questions we don't know the answers to, authentic questions that people really wonder about" (Harvey, 2002, p. 15). In this study, the children's questions were analyzed and found to serve two main purposes, a tool for clarification and an expression of their opinions.

\section{Questioning for Clarification}

In this category, the children asked questions to clarify something they couldn't understand. We are discussing the scene where Joaquín is about to be stoned as some neighborhood boys are chasing him out of the pueblito. This scene raised considerable concern; the children simply could not understand why anyone would want to hurt Joaquin especially since he had done nothing wrong. Each of the four children addressed this situation.

J- $\quad$ Yo no entiendo por que le querían pegar al Joaquín con una piedra si el no les estaba haciendo nada y ellos le andaban buscando pleito y el no les estaba haciendo nada, ¿para qué le querían pegar?

[I don't understand why they wanted to hit Joaquin with rocks when he wasn't doing anything and they were just looking for trouble and he wasn't doing anything, why did they want to hurt him?]

M- ¿Que porqué le van a pegar, si él no esta haciendo nada malo? El es el amigo de la...

[Why are they going to hurt him if he isn't doing anything wrong? He's friends with...]

J- Prietita

M- $\quad$ Prietita, él es amigo de la Prietita y porque le quieren pegar a él, porque creen que el es 'mojado', pero todavía no entiendo porque le querían pegar. 
[Prietita, he's friend with Prietita and why do they want to hurt him because they think he is a 'wetback', but I still don't understand why they want to hurt him.]

J- ¿ ¿Por qué le querían tirar una piedra si él no más iba a salir de la casa de Prietita, ya se iba ir, y no los, na'más ellos pararon y le quisieron hacer daño?

[Why did they want to throw a rock at him if he was just leaving Prietita's house, and he was leaving, and he didn't, they just stopped and wanted to throw a rock at him?]

R- ¿YYo digo, que por qué le querían pegar si ellos también son 'mojados'?

[I say, why did they want to hurt him if they are also 'wetbacks'?]

The children simply couldn't come to terms with why the boys [in the story] wanted to hurt Joaquin, especially since he had done nothing to warrant this action. They empathized with Joaquin as they grappled with this unanswerable question; ¿Por qué le querían pegar a Joaquín? [Why did they want to hurt Joaquin?] Rosita added to the bewilderment when she commented, "ellos también son mojados." [They are also wetbacks.]

In her study with fourth/fifth graders Enciso (1994) noticed that the children tried to stay away from issues of racial difference, "they either reframed the problems of race or agued that difference does not really matter" (p. 530). For my students however, the issue of race came up almost immediately, "¿Porqué le dicen mojado si ellos también viven en México, pa'que le dicen, se ellos también son? Why do they call him a wetback if they also live in Mexico, why do they say that if they are wetbacks too? My student's awareness of their cultural selves allowed them to "draw on a vast storehouse of cultural knowledge as they explore and declare who they are and how they want to be seen as members of a classroom and community" (Enciso, 1994, p. 524).

\section{Questions as Expressions of Opinion}

Throughout the discussion the children readily expressed their opinions through the use of questions. They would pose a question and immediately respond with their opinion or give their opinion to a question posed by someone else. Because an atmosphere of respect and safety was created in our classroom, 
the children felt safe in sharing their opinions freely.

¿Cómo porqué en los pueblitos es donde más busca la Border Patrol? Porque alli saben que hay muchos porque cuando Itur el río, Itur como, llegan como aquí.

[Why is it that the Border Patrol looks more [for wetbacks] in the small villages? Because they know that's where they are because when the cross the river, they cross and like, they come here.]

Javier was referring to the part in the book when the Border Patrol has just arrived in the pueblito where Joaquin and his mother live. The scene depicts Prietita taking Joaquin and his mother to the curanderas house to seek refuge.

¿Para qué le querían pegar? Y luego también a ellos porque no les da vergüenza si el esta bien flaquito y ellos están bien gordos; ya comieron y el no.

[Why did they want to hurt him? And also why aren't they ashamed of themselves, he's so skinny and they're nice and fat; they have eaten and he hasn't.]

In her response Jasmine was trying to understand why someone who is 'well- fed' would try to hurt someone who was hungry. She also wonders why the boys don't feel ashamed for wanting to take action against someone who is not their equal.

The children's questions were used as part of their meaning making. They were trying to understand their place in the world by questioning the actions and motives of others, who in this situation were of the same cultural background as themselves. The questions also helped the children make sense out of what was happening and frame it in a context familiar to them.

\section{Interpreting}

The children often simply stated what they felt about the situation in the text and its relation to their lives. This category of Interpreting includes the children's personal reactions and their opinions as a search for understanding and for a solution to the problem. The two subcategories are; Searching for Understanding and Drawing Conclusions. 


\section{Interpreting: Searching for Understanding}

As we have seen, many of the children's responses came from their discussing lived-through experiences, experiences that either impacted them directly or indirectly. When the children shared these experiences, they were trying to make sense of them in relation to what was happening in the text. Searching for understanding includes responses that had to do with what they understood to be happening in the world from listening to adults speak or from watching the evening news.

T- ¿Qué piensan, qué esta bien o mal que la migra se lleve a la gente que viene sin papeles?

[What do you think, is it right or wrong for the migra to take people that have no papers?

All- Esta mal. It's wrong.

M- Muy mal. Very wrong.

T- ¿Porqué está muy mal? [Why is it 'very wrong'?]

M- La gente necesita, um, pasar para acá para buscar trabajo, o reunirse con su familia, para que no se mueran. Dijeron en las noticias que a lo mejor Vicente Fox, el um, presidente de México, va quitar a los inmigrantes y a todos los 'mojaditos' lo va agarrar y les van a dar los papeles para que no se estén brincando el cerco.

[People need to, um, come over here to look for work, or reunite with their families so they don't die. They said in the news that maybe, Vicente Fox, um, the President of Mexico, was going to do away with the immigrants, and all the 'wetbacks' he's going to grab them and give them all papers so they won't have to jump the fence.]

All of the children, especially Miguel, were well aware of the ongoing struggle of Mexican immigrants; first to make it into the United States alive and second to find a means of support for their families. As a class we discussed the deaths in the desert due to the extreme heat and unpreparedenss of the immigrants to face the elements, and the fact that many of the immigrants were children. We also discussed coyotes, smugglers, and how they took advantage of these poor people. We talked about what was printed in the newspapers, what their parents and families were talking about and what was said in the American news casts as well as the Mexican newscasts. The children were informed. From this information, they were able to formulate 
their own opinions and again try to make sense of it all by finding their place in the world and its relation to them.

\section{Interpreting: Drawing Conclusions}

The children, as discussed above, were well informed of the plight of the Mexican immigrant in Southern Arizona. Interpreting: Drawing Conclusions includes responses where the children openly and honestly talked about the issue of illegal entry into the United States, the children were able to formulate their own opinions and as we shall see in this section, offer solutions.

Yo no, yo no entiendo porque la policia, no la migra, unos de esos dos, trozaron la puerta, porqué tocan y luego tienen que abrir.

[I don't understand why the police, no the migra, on of the two knocked on the door in, because you knock, and then someone is supposed to open [the door].]

Jasmine repeated this question several times and finally offered a solution;

Y no tienen que hacer eso, pueden tocar en la puerta, luego alguien, un adulto grande, viene y abre la puerta y le dice 'Si no tiene papeles, venga para acá, me voy a llevarlos', no los tienen que agarrar de la mano, que habrán la puerta y que entren tranquilos.

They Border Patrol don't have to do that, they can knock on the door, then someone, a grown adult, opens the door and then they say 'If you don't have papers, come with me, I am going to take you away. They don't have to grab them by the hands, they should just open the door and enter peacefully.]

Jasmine's proposed resolution is peaceful; the Border Patrol calmly knocks on the door and once opened, simply requests that anyone without papers come with them. In her eyes this would work, because as she added in an interview, "La gente no es toda mala." [People aren't all bad.] Wouldn't it be nice if this were the solution?

Jasmine later shares that the Border Patrol should have the papers with them so that "cuando llegan a una casa y no tienen papeles, le pueden ayudar a llenarlos." [When they [Border Patrol] arrive at a house and they [immigrants] don't have papers, they can help fill them out.] Again, in her eyes an ideal and practical solution. Jasmine repeated this theme of proposing a solution 
throughout the transcript and later in her interview. Although she had no personal experience with the Border Patrol as Rosita did, this part of the boook meant enough to her that she struggles to find solutions to the problem.

\section{Discussion}

This study explored how linguistically diverse second graders from lower socioeconomic backgrounds made meaning through discussing issues that are related to their lives in a small group literature discussion. The children discussed issues of racism, poverty, illegal immigration and deportation; Rosita told of the day she and her brother came home and found that the Border Patrol had taken both their parents back to Mexico, Jasmine searched for a peaceful solution to illegal border crossing, Miguel talked about his helping the mojadito by warning him of the 'migra' and Javier questioned why the Border Patrol only seached for illegals in the pueblitos.

The children relied on and shared their life experiences to help them make sense of the text. Rosenblatt (1938) explains, It is easy to observe how the beginning reader draws on past experience of life and language to elicit meaning from the printed words, and it is possible to see how through these words he reorgnizes past experiences to attain new understanding. (p. 25)

Together the children were searching to understand what was happening to Joaquin as they examined their past experiences as a ltu to gain an understanding of a new situation.

The study illustrates that through sharing, questioning and interpreting, the children each came to some sort of personal understanding of the issues raised in the text and that they related the text to events in their own lives. Battle (1992) expounds,

Consistent with Vygotsky's (1978) social constructivist theory, the interactions or dialogues about stories read aloud should provide opportunities for questions to be posed, meanings to be constructed and clarified, background knowledge to be extended, and connections to life experiences and other literary works to be made. (p. 163)

Literature discussions gave us the opportunity to participate in authentic language situations where the children truly believed that their classmates and I had a genuine interest in what they had to say. The children learned that ex- 
pressing one's opinions and ideas is not as easy as it seems. Bakhtin (1981) believes that, "Language is not a neutral ltur that passes freely and easily into the private property of the speakers intentions...forcing it to submit to one's own intentions and accents, is a difficult and complicated process" (p. 294).

\section{Conclusion}

Edelsky (1999) says, "Classroom literacy can never be politically neutral. Literacy can be taught either as a tool of critical inquiry or passive transmisión. It can be a vehicle for posing and solving important social problems or for accepting official explanations or solutions" (p. xi). Literature discussions give my students the opportunity to critically examine thought provoking books and have them think about critical issues.

Linguistically and socioeconomically diverse learners bring a wealth of knowledge to school. Their ways of knowing, although not consistent with those of the majority [culture], are to be respected. These learners are in no way 'deficient', they are bringing experiences that differ from those of the group in power and for that reason are seen as lacking. We must respect the knowledge they bring to our classrooms and work together with them to create new understandings and make connections between what they already know and what they are learning.

\section{References}

Bakhtin, M. (1981). Discourse in the novel. In M. Holquist (Ed.), The Dialogic Imagination: Four Essays by M. Bakhtin (pp. 259-422). Austin: University of Texas Press.

Barnes, D. (1990). Oral language and learning. In S. Hynds \& D.L. Rubin (Eds.), Perspectives on talk and learning (pp. 41-54).

Barnes, D.(1993). Supporting exploratory talk for learning. In K.M. Pierce \& C.J. Gilles (Eds.), Cycles of Meaning: Exploring the potential of talk in learning communities Portsmouth, $\mathrm{NH}$ : Heinemann, (pp. 17-34).

Battle, J.(1993). Mexican-American Bilingual Kindergartners' Collaborations in meaning making. National Reading Conference Yearbook,42, 163-169

Brock, C. (1997). Exploring the use of book club with second language learners in mainstream classrooms. In S. McMahon \& T. Raphael (Eds.), The book club connection: Literacy learning and classroom talk (pp. 141-158). New York: Teachers College Press. 
Cochran-Smith, M. (1984).The making of a reader. Norwood, NJ: Ablex Publishing Corporation.

Cochran-Smith, M., \& Lytle, S. (1993). Inside/Outside teacher research and knowledge. New York: Teachers College Press.

Commeyras, M. (1994). Were Janell and Neesie in the same classroom? Children's questions as the first order of reality in storybook discussions. Language Arts,71,517-523.

Cox, C., \& Boyd-Batstone, P. (1997). Crossroads: Literature and language in culturally and linguistically diverse classrooms. Upper Saddle River: NJ: Prentice Hall.

Cummins, J.(1989). Empowering minority students. Sacramento: CA: California Association for Bilingual Educators.

Cummins, J. (1986). Empowering minority students: A framework for intervention. Harvard Educational Review 56 (1), 18-36.

Delpit, L.(1995). Other People's Children: Cultural conflict in the classroom. New York: New Press.

Dewey, J. (1938). Experience and education. New York: Touchstone.

Diaz, S., Moll, L., \& Mehan, H. (1990). Sociocultural resources in instruction: A context specific approach. $4^{\text {th }}$ ed. Beyond language: Social and cultural factors in schooling language minority students ((pp. 187-230). Los Angeles, CA: Evaluation, Dissemenation and Assessment Center.

Duckworth, E. (1996). The having of wonderful ideas and other essays on teaching and learning. ( $2^{\text {nd }}$ ed.), New York: Teachers College Press.

Dyson, A.H. \& Geneshi, C. (1994). Introduction. In A.H. Dyson \& C. Geneshi (Eds.), The need for story: Cultural diversity in classroom and community (pp. 1-7). Urbana, IL: National Council of Teachers of English.

Dyson, A.H. (1993). Social worlds of children learning to write in an urban primary school. New York: Teachers College Press.

Edelsky, C. (1999). Introduction. In C. Edelsky (Ed.), Making justice our project: Teachers working toward critical whole language practice (pp. I-xii). Urbana, IL: National Council of Teachers of English.

Enciso, P. E. (1994). Cultural identity and response to literature: Running lessons from Maniac McGee. Language Arts,71, 524-533.

Ferriero, E. \& Teberosky, A. (1982). Literacy before schooling. Exeter, NH: Heinemann.

Freire, P. (1991). The importance of the act of reading. In C. Mitchell \& K. Weiler (Eds.), Rewriting literacy; Culture and the discourse of the other (pp. 139-145). Westport, CT: Greenwood Publishing Group, Inc.

Glasser ,B. \& Strauss, A. (1967). The discovery of grounded theory. New York: Aldine.

Goodman, K.S. (1986). What's whole in whole language? Portsmouth, NH: Heinemann. 
Goodman, Y.M. \& Goodman, K.S. ( 1990). Vygotsky in a whole-language perspective. In L.C. Moll (Ed.), Vygotsky and education: Instructional implications and applications of sociohistorical psychology (pp. 223-250). Cambridge, UK: Cambridge University Press.

Harvey, S. (2002). Nonfiction inquiry: Using real reading and writing to explore the world. Language Arts, 80, 12-22.

Heath, S.B. (1983). Ways with words: Language, life, and work in communities and classrooms. Cambridge, UK: Cambridge University Press.

Klassen, C. (1993). Exploring "the color of peace ": Content-area literature discussions. In K.M. Pierce \& C. Gilles (Eds.), Cycles of meaning: Exploring the potential of talk in learning communities (pp. 237-259). Portsmouth, NH: Heinemann.

Martínez, M., Roser, N., Hoffman, J., \& Battle, J. (1992). Fostering better book discussions through response logs and a response framework: A case description. Literacy research, theory and practice: Views from many perspectives. National Reading Conference Yearbook, 41, 303-311.

Martínez-Roldán, C. \& López-Robertson, J. (1999). Initiating literature circles in a first-grade bilingual classroom. The Reading Teacher, 53(4), 270-281.

McGee, L. (1992). An exploration of meaning construction is first graders' grand conversations. Literacy research, theory and practice: Views from many perspectives. National Reading Conference Yearbook,41, 177-186.

Moll, L.C. (Ed). (1990). Vygotsky and education: Instructional implications and applications of sociohistorical psychology. Cambridge, UK: Cambridge University Press.

Moll, L.C., Díaz, S., Estrada, B. \& López, L. (1992). Making contexts: The social construction of lessons in two languages. In M.Samvia-Shore \& S.F. Arvizu (Eds.), Crosscultural literacy: Ethnographies of communication in multiethnic classrooms (pp. 339-366). New York: Garland.

Moraes, M. (1996). Bilingual education: A dialogue with the Bakhtin circle. Albany, NY: State University of New York Press.

Ochs, E. (1979). Transcription as theory. In Ochs, E. \& Schieffelin, B. (Eds.), Developmental pragmatics (pp.43-72). London, UK: Academic Press Inc..

Powell, R.G. (1989). Johnny can't talk either: The perpetuation of the deficit theory in classrooms. The Reading Teacher, 42, 670-674.

Purcell-Gates, V. (1995). Other People's Words: The cycle of low literacy. Cambridge, MA: Harvard University Press.

Raphael, T., Brock, C., \& Wallace, S. (1997). Encouraging quality peer talk with diverse students in mainstream classrooms: Learning from and with teachers. In J.Paratore \& R. McCormack (Eds.), Peer talk in the classroom: Learning from research (pp. 177-206). Newark, DE: International Reading Association.

Roller, C.M. \& Beed, P.L. (1994). Sometimes the conversations were grand, and some- 
times.... Language Arts,71, 509-515.

Rosenblatt, L. (1938). Literature as exploration. New York: The Modern Language Association.

Seidman, I. (1998). Interviewing as qualitative research: A guide for researchers in education and the social sciences. New York: Teachers College Press.

Short, K. (1997). Literature as a way of knowing. York, ME: Stenhouse.

Short, K. (1995). Foreward. In B. Campbell Hill, N.J. Johnson \& K.L. Schlick Noe (Eds.), Literature circles and response (pp. ix-xii). Norwood, MA: Christopher Gordon Publishers.

Sipe,L.R. (1998). Individual literary response styles of first and second graders. National Reading Conference Yearbook,47, 76-89.

Valdés, G. (1996). Con respeto: Bridging the distances between culturally diverse families and schools. New York: Teachers College Press.

Vygotsky, L.S. (1978). Mind in society: The development of higher psychological processes. Cambridge, MA: Harvard University Press.

Wollman-Bonilla, J.E. (1994). Why don't they "just speak?" Attempting literature discussion with more and less able readers. Research in the Teaching of English,28(3),231-258. Children's Books Cited

Anzaldúa, Gloria. (1993) Friends from the other side/Amigos del otro lado. San Francisco: Children's Book Press.

\section{THE AUTHOR}

Julia Lopez-Roberstonis Adjunct Assistant Professor at the University of Arizona. She is a Bilingual Second Grade Teacher at Hollinger Elementary School in Tucson, Arizona USA. E-mail: jlrchikca@msn.com 